\title{
A comparative study of nemertean complete mitochondrial genomes, including two new ones for Nectonemertes cf. mirabilis and Zygeupolia rubens, may elucidate the fundamental pattern for the phylum Nemertea
}

Hai-Xia Chen ${ }^{1,2}$, Shi-Chun Sun ${ }^{2}$, Per Sundberg ${ }^{1}$, Wei-Cheng Ren ${ }^{3}$ and Jon L Norenburg ${ }^{4^{*}}$

\begin{abstract}
Background: The mitochondrial genome is important for studying genome evolution as well as reconstructing the phylogeny of organisms. Complete mitochondrial genome sequences have been reported for more than 2200 metazoans, mainly vertebrates and arthropods. To date, from a total of about 1275 described nemertean species, only three complete and two partial mitochondrial DNA sequences from nemerteans have been published. Here, we report the entire mitochondrial genomes for two more nemertean species: Nectonemertes cf. mirabilis and Zygeupolia rubens.
\end{abstract}

Results: The sizes of the entire mitochondrial genomes are $15365 \mathrm{bp}$ for N. cf. mirabilis and $15513 \mathrm{bp}$ for Z. rubens. Each circular genome contains 37 genes and an AT-rich non-coding region, and overall nucleotide composition is AT-rich. In both species, there is significant strand asymmetry in the distribution of nucleotides, with the coding strand being richer in $T$ than $A$ and in $G$ than $C$. The AT-rich non-coding regions of the two genomes have some repeat sequences and stem-loop structures, both of which may be associated with the initiation of replication or transcription. The 22 tRNAs show variable substitution patterns in nemerteans, with higher sequence conservation in genes located on the $\mathrm{H}$ strand. Gene arrangement of $\mathrm{N}$. cf. mirabilis is identical to that of Paranemertes cf. peregrina, both of which are Hoplonemertea, while that of $Z$. rubens is the same as in Lineus viridis, both of which are Heteronemertea. Comparison of the gene arrangements and phylogenomic analysis based on concatenated nucleotide sequences of the 12 mitochondrial protein-coding genes revealed that species with closer relationships share more identical gene blocks.

Conclusion: The two new mitochondrial genomes share many features, including gene contents, with other known nemertean mitochondrial genomes. The tRNA families display a composite substitution pathway. Gene order comparison to the proposed ground pattern of Bilateria and some lophotrochozoans suggests that the nemertean ancestral mitochondrial gene order most closely resembles the heteronemertean type. Phylogenetic analysis proposes a sister-group relationship between Hetero- and Hoplonemertea, which supports one of two recent alternative hypotheses of nemertean phylogeny.

Keywords: MtDNA, Nemertea, Nectonemertes mirabilis, Zygeupolia rubens, Phylogeny, Gene rearrangement

\footnotetext{
* Correspondence: norenburgj@si.edu

${ }^{4}$ Department of Invertebrate Zoology, National Museum of Natural History,

Smithsonian Institution, Washington, DC 20560-0163, USA

Full list of author information is available at the end of the article
} 


\section{Background}

Knowledge of mitochondrial genomes is important for many scientific disciplines $[1,2]$ and the relative arrangement of mitochondrial genes has been effective for studying phylogenetic relationships $[3,4]$. However, current knowledge of mtDNAs is uneven, and sequences available in GenBank are predominantly from vertebrate taxa. There are about 1275 described species [5] of nemerteans (ribbon worms, phylum Nemertea); these are mainly marine but terrestrial and freshwater species also are known. To date, complete mitochondrial genomes have been published for only three species in the phylum, Cephalothrix hongkongiensis (Palaeonemertea) [reported as Cephalothrix simula in [6]], Lineus viridis (Heteronemertea) [7], and Paranemertes cf. peregrina (Hoplonemertea)[8]. Nearly complete sequences exist for the palaeonemerteans Cephalothrix sp. [8] and Cephalothrix rufifrons [9]. Thus, current genomic knowledge of nemerteans is scant and taxon diversity is poorly sampled. In this study, we sequenced the complete mitochondrial genomes of two nemertean species, Nectonemertes cf. mirabilis (Hoplonemertea: Polystilifera) and Zygeupolia rubens (Heteronemertea). Mitochondrial gene arrangements, structures, and compositions, as well as translation and initiation codons and codon usage patterns, were compared with complete mtDNA sequences of other nemerteans. In addition, we compare gene order among Lophotrochozoa and we use the nucleotide sequences to analyze phylogenetic relationship among the included nemerteans.

\section{Results and discussion}

\section{Genome organization and structure}

Genome composition and gene arrangement of Nectonemertes cf. mirabilis and Zygeupolia rubens are summarized in Figure 1 and Table 1. The mitochondrial genomes of $N$. cf. mirabilis and $Z$. rubens are circular DNA molecules of 15365 bp and 15513 bp, respectively. Lengths of the two nemertean mitochondrial genomes are within the range of previously sequenced nemertean mtDNAs - 14558 bp in Paranemertes cf. peregrina to 16296 bp in Cephalothrix hongkongiensis [6]. Both of the newly sequenced mitochondrial genomes contain 37 genes, including 13 protein-coding genes, two ribosomal RNAs, and 22 transfer RNAs. All genes except trnP and $\operatorname{trn} T$ are encoded on the same strand (Figure 1).

For both species, protein-coding genes nad4L and nad4 share an overlap, by seven nucleotides, and nad6 overlaps cob by eight nucleotides in Z. rubens (Figure 1, Table 1). Such overlaps are common to all known mtDNA genomes of nemerteans [6,8], and are found in many metazoan mtDNAs [10].

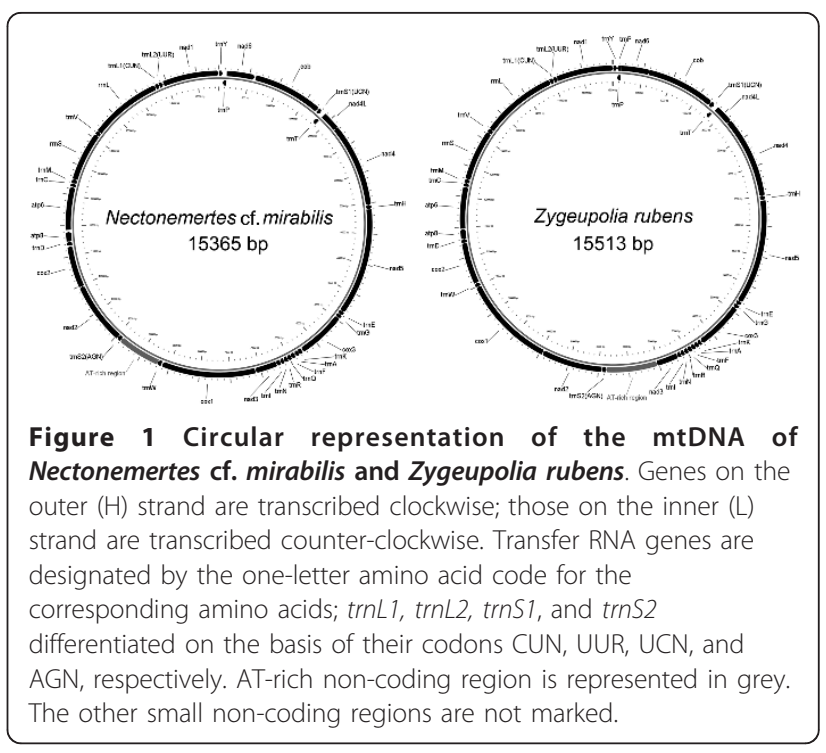

\section{Protein-coding genes}

Thirteen protein-coding genes (cox1-cox3, nad1-nad6, $n a d 4 L, c o b, a t p 6$, and $\operatorname{atp} 8)$ were identified. Mitochondrial genomes often use a variety of nonstandard initiation codons [11]. Except for nad4 (GTG), nad5 (GTG), atp8 (GTG) and atp6 (GTT) in N. cf. mirabilis, and nad1 (GTG) and nad2 (GTG) in Z. rubens, the proteincoding genes of both species begin with ATG. The majority of genes in both species contain the full termination codon TAA or TAG, but some end with T (atp8 in N. cf. mirabilis, and nad5, cox 2 and nad1 in $Z$. rubens). Such abbreviated stop codons are common among animal mitochondrial genes. In $Z$. rubens, the incomplete stop codons are immediately followed by the downstream tRNA gene (Figure 1, Table 1), whose secondary structure has been suggested to act as a signal for the cleavage of the polycistronic primary transcript $[12,13]$. However, there also are direct junctions pairing ten protein-coding genes in $N$. cf. mirabilis (nad6/cob, nad4L/nad4, nad3/cox1, nad2/cox2, and atp8/atp6) and eight in Z. rubens (nad6/cob, nad4L/nad4, nad2/cox1 and atp8/atp6) (Figure 1, Table 1). Here, cleavage signals other than secondary structure of a tRNA gene may initiate processing of the polycistronic primary transcript [14]. For two protein-coding genes (nad6 and nad2) in both nemertean species and nad3 in N. cf. mirabilis, stem-loop structures were inferred to be at the 3' end and abutting the 5 ' end of the neighboring proteincoding gene, and may signal cleavage of the immature mRNA $[15,16]$.

\section{Transfer RNA and ribosomal RNA genes}

Both of the mitochondrial genomes encoded 22 tRNA genes found in other nemertean mtDNAs, which is 
Table 1 Location of genes in the mitochondrial genomes of Nectonemertes cf. mirabilis and Zygeupolia rubens

\begin{tabular}{|c|c|c|c|c|c|c|c|}
\hline \multicolumn{4}{|c|}{ Nectonemertes cf. mirabilis } & \multicolumn{4}{|c|}{ Zygeupolia rubens } \\
\hline Genes & From 5'to $3^{\prime}$ & Size (bp) & $3^{\prime}$ spacer $^{a}$ & Genes & From 5'to $3^{\prime}$ & Size (bp) & $3^{\prime}$ spacer $^{a}$ \\
\hline $\operatorname{trn} Y$ & $1-62$ & 62 & 0 & $\operatorname{trn} Y$ & $1-64$ & 64 & 0 \\
\hline $\operatorname{trn} P^{b}$ & $125-63$ & 63 & 2 & $\operatorname{trn} P^{\mathrm{b}}$ & $131-65$ & 67 & 3 \\
\hline nad6 & $128-583$ & 456 & 21 & nad6 & $135-599$ & 465 & -8 \\
\hline$c o b$ & $605-1741$ & 1137 & 9 & $c o b$ & $592-1728$ & 1137 & -1 \\
\hline trnS1 (UCN) & $1751-1811$ & 61 & -1 & $\operatorname{trnS1}(\mathrm{UCN})$ & $1728-1798$ & 71 & -1 \\
\hline $\operatorname{trn} T^{\mathrm{b}}$ & $1876-1811$ & 66 & 2 & $\operatorname{trn} T^{\mathrm{b}}$ & $1861-1798$ & 64 & 2 \\
\hline nad4L & $1879-2181$ & 303 & -7 & nad4L & $1864-2169$ & 306 & -7 \\
\hline nad4 & $2175-3536$ & 1362 & 6 & nad4 & 2163-3509 & 1347 & 1 \\
\hline $\operatorname{trnH}$ & $3543-3602$ & 60 & 0 & $\operatorname{trnH}$ & $3511-3574$ & 64 & 2 \\
\hline nad5 & $3603-5348$ & 1746 & -1 & nad5 & $3577-5308$ & 1732 & 0 \\
\hline trnE & $5348-5410$ & 63 & 1 & $\operatorname{trn} E$ & 5309-5372 & 64 & 1 \\
\hline $\operatorname{trn} G$ & $5412-5474$ & 63 & 2 & $\operatorname{trn} G$ & $5374-5438$ & 65 & 2 \\
\hline $\cos 3$ & $5477-6256$ & 780 & 9 & $\cos 3$ & $5441-6220$ & 780 & 6 \\
\hline trnk & $6266-6332$ & 67 & -2 & trnk & $6227-6287$ & 61 & -1 \\
\hline $\operatorname{trn} A$ & 6331-6393 & 63 & 5 & $\operatorname{trn} A$ & $6287-6350$ & 64 & 0 \\
\hline $\operatorname{trnF}$ & $6399-6464$ & 66 & 1 & $\operatorname{trnF}$ & 6351-6415 & 65 & 0 \\
\hline $\operatorname{trn} Q$ & $6466-6532$ & 67 & 0 & $\operatorname{trn} Q$ & 6416-6484 & 69 & 0 \\
\hline $\operatorname{trn} R$ & $6533-6598$ & 66 & 1 & $\operatorname{trn} R$ & $6485-6550$ & 66 & 1 \\
\hline $\operatorname{trn} N$ & $6600-6662$ & 63 & 2 & $\operatorname{trn} N$ & $6552-6616$ & 65 & 0 \\
\hline trnl & $6665-6730$ & 66 & 1 & trnl & $6617-6681$ & 65 & 1 \\
\hline nad3 & $6732-7085$ & 354 & 5 & nad3 & 6683-7039 & 357 & 0 \\
\hline $\cos 1$ & $7091-8626$ & 1536 & 12 & AT-rich & 7040-7877 & 838 & 0 \\
\hline $\operatorname{trn} W$ & 8639-8703 & 65 & 0 & $\operatorname{trn} S 2(A G N)$ & 7878-7949 & 72 & 0 \\
\hline AT-rich & $8704-9405$ & 702 & 0 & nad2 & $7950-8957$ & 1008 & 3 \\
\hline $\operatorname{trnS2}(\mathrm{AGN})$ & $9406-9473$ & 68 & -1 & $\cos 1$ & 8961-10493 & 1533 & 0 \\
\hline nad2 & $9473-10480$ & 1008 & 5 & $\operatorname{trn} W$ & 10494-10558 & 65 & 3 \\
\hline $\operatorname{cox} 2$ & 10486-11166 & 681 & 14 & $\cos 2$ & $10562-11246$ & 685 & 0 \\
\hline $\operatorname{trn} D$ & 11181-11245 & 65 & 0 & $\operatorname{trn} D$ & 11247-11312 & 66 & 0 \\
\hline atp8 & 11246-11402 & 157 & 40 & atp8 & 11313-11471 & 159 & 5 \\
\hline atp6 & 11443-12132 & 700 & 5 & atp6 & 11477-12169 & 693 & 1 \\
\hline $\operatorname{trn} C$ & 12138-12198 & 61 & 0 & $\operatorname{trn} C$ & 12171-12232 & 62 & 0 \\
\hline $\operatorname{trn} M$ & 12199-12263 & 65 & 0 & $\operatorname{trnM}$ & 12233-12296 & 64 & 0 \\
\hline$r r n s$ & 12264-13068 & 805 & 0 & $r r n s$ & 12297-13132 & 836 & 0 \\
\hline $\operatorname{trnV}$ & 13069-13130 & 62 & 0 & $\operatorname{trnV}$ & 13133-13200 & 68 & 0 \\
\hline$r r n L$ & 13131-14308 & 1178 & 0 & $r r n L$ & 13201-14448 & 1248 & 0 \\
\hline $\operatorname{trn} L 1(\mathrm{CUN})$ & 14309-14372 & 64 & 1 & $\operatorname{trn} L 1(\mathrm{CUN})$ & 14449-14515 & 67 & 0 \\
\hline $\operatorname{trn} L 2$ (UUR) & 14374-14435 & 62 & 2 & $\operatorname{trn} L 2(U \cup R)$ & 14516-14582 & 67 & 0 \\
\hline nad1 & $14438-15361$ & 924 & 4 & nad1 & $14583-15513$ & 931 & 0 \\
\hline
\end{tabular}

${ }^{a}$ Negative numbers indicate that genes were overlapping

${ }^{b}$ Genes coding in $L$ strand

typical of animal mitochondrial genomes [10]. They varied from $60(\operatorname{trn} H)$ to $68(\operatorname{trnS2})$ nucleotides in $N$. cf. mirabilis and 61 (trnK) to $72(\operatorname{trnS2})$ nucleotides in $Z$. rubens (Table 2); most were folded into a typical cloverleaf secondary structure (Figures 2, 3). The postulated
tRNA cloverleaf structures generally contained $7 \mathrm{bp}$ in the aminoacyl stem, 2 to $5 \mathrm{bp}$ in the T $\psi \mathrm{C}$ stem, $5 \mathrm{bp}$ in the anticodon stem, and 0 to $4 \mathrm{bp}$ in the dihydrouridine (DHU) stem. Some tRNAs showed DHU-loop replacement (e.g., trnS1 of $N$. cf. mirabilis), as also found in $L$. 
Table 2 Base composition of the mtDNA in six nemerteans

\begin{tabular}{|c|c|c|c|c|c|c|c|c|c|}
\hline Species & Total nt & $\mathrm{T}$ & C & A & G & $A+T$ & AT skew & GC skew & References \\
\hline Cephalothrix hongkongiensis & 16296 & 47.4 & 10.2 & 27.5 & 14.9 & 74.9 & -0.266 & 0.187 & [6] \\
\hline Cephalothrix sp. & 15800 & 47.9 & 10.0 & 27.8 & 14.3 & 75.7 & -0.266 & 0.178 & [8] \\
\hline Paranemertes cf. peregrina & 14558 & 47.5 & 10.0 & 22.8 & 19.7 & 70.3 & -0.351 & 0.322 & {$[8]$} \\
\hline Nectonemertes cf. mirabilis & 15365 & 48.5 & 10.5 & 21.8 & 19.2 & 70.3 & -0.380 & 0.293 & Present study \\
\hline Lineus viridis & 15388 & 44.4 & 11.9 & 21.3 & 22.4 & 65.7 & -0.352 & 0.306 & [7] \\
\hline Zygeupolia rubens & 15513 & 45.0 & 9.8 & 21.0 & 24.2 & 66.0 & -0.364 & 0.424 & Present study \\
\hline
\end{tabular}

viridis and $P$. cf. peregrina. In general, the lack of a DHU arm in two serine tRNAs is a common condition in metazoan mtDNAs [17]. The presence of such aberrant tRNA genes in mitochondrial genomes could be due to modification of tRNA secondary structure by replication slippage [18], or selection for mitochondrial genome minimization [19].

The mtDNAs of nemerteans investigated to date all have 20 tRNAs on the $\mathrm{L}$ strand and 2 tRNAs on the $\mathrm{H}$ strand ([6-9]). Secondary structures of nemertean tRNAs are presented and compared in Figures 2 and 3 (pattern follows [20]). Table 3 presents the tRNA lengths and the percent of identical nucleotides (\%INUC) for the six nemerteans.

Nucleotide conservation was strongest on the $\mathrm{H}$ strand, with $\operatorname{trn} C$, $\operatorname{trn} G$ and $\operatorname{trn} M$, having the highest levels of nucleotide conservation (\%INUC > 50), followed by $\operatorname{Trn} E, \operatorname{trn} L 2, \operatorname{trn} Q, \operatorname{trnS} 2, \operatorname{trn} V$ and $\operatorname{trn} Y$ at 40 $\leq \% \mathrm{INUC} \leq 50$ (Figure 2). The ten remaining tRNAs had \%INUC values between 30 and 40; eight - trnD, $\operatorname{trn} F, \operatorname{trn} H, \operatorname{trn} I, \operatorname{trn} K, \operatorname{trn} L 1, \operatorname{trn} S 1$ and $\operatorname{trn} W$ - are located on the $\mathrm{H}$ strand, while two - $\operatorname{trn} P$ and $\operatorname{trn} T$ - are on the $\mathrm{L}$ strand. $\mathrm{H}$-strand genes $\operatorname{trn} A, \operatorname{trn} N$ and $\operatorname{trn} R$ had \%INUC values $\leq 30$.

Conservation was positively $\mathrm{H}$ strand-biased, but no other pattern could be identified with respect to location of tRNAs along the genome. Two of the three most conserved tRNAs, $\operatorname{trn} C$ and $\operatorname{trn} M$, are adjoining, while the third, $\operatorname{trn} G$, adjoins the moderately conserved $\operatorname{trn} E$ and is relatively close to the three least conserved genes, $\operatorname{trn} A, \operatorname{trn} N$ and $\operatorname{trnR}$ (Figure 1, Table 1). As observed by others (e.g., [20]), there was no self-evident link between abundance of codon families and the level of tRNA conservation, with the most abundant codon families (Leu2, Ile and Phe) not having the highest \%INUCs (see below).

A few mismatched nucleotide pairs (e.g., G-A, A-A, T$\mathrm{C}, \mathrm{T}-\mathrm{T}$ ) were found in the acceptor and/or the discriminator arms, without regard to the overall level of conservation of the tRNAs. As recently pointed out by Negrisolo et al. [20] for arthropods, metazoan mtDNAs commonly have such mismatches. It has been suggested that these may be corrected via RNA-editing mechanisms (e.g., [17]) or they may represent unusual pairings [21].

Among the most conserved tRNAs in nemerteans, as in insects (e.g., [20]), nucleotide substitutions are mostly confined to TYC and DHU loops and extra arms (Figures 2,3), with 2-7 fully compensatory base changes (cbc; e.g., G-C vs. A-T) or hemi-cbcs (e.g., T-A vs. T-G) on acceptor and anticodon stems (see $[20,22]$ ). As in insects [20], the number of cbcs and hemi-cbcs increased in stems as overall variation increased, especially in the $\mathrm{T} \Psi \mathrm{C}$ stem.

As found in insects, cbcs and hemi-cbcs characterized either single species or taxa at a higher taxonomic rank. An example of the first type is the A-T pair found in the $\operatorname{trn} C$ acceptor arm of $P$. cf. peregrina, which was mirrored by G-C in all other nemerteans (Figure 2). Few substitutions were present among $C$. hongkongiensis and Cephalothrix sp. (Figures 2, 3). An example of a full cbc characterizing a unique family is the A-T pair found in the acceptor stem of trnL1s of family Lineidae (L. viridis and $Z$. rubens), while other taxa exhibited the G-C pair (Figure 2). Similarly, a full cbc in the anticodon stem of $\operatorname{trn} G$ of two hoplonemerteans characterizes another high-taxonomic rank (Figure 2). Figures 2 and 3 depict several more examples. This points to the potential phylogenetic value of tRNA sequences, as demonstrated for other animal groups (e.g., $[20,23])$, especially when secondary structures are taken into account [20]. While encouraging, clearly we need substantially more nemertean mitochondrial genomes to test this assertion for nemerteans.

The anticodon usage of $N$. cf. mirabilis and Z. rubens was congruent with the corresponding tRNA genes of other nemerteans, with one exception. The anticodon of the trnS2 (AGN) gene in $N$. cf. mirabilis, $P$. cf. peregrina and three Cephalothrix species is GCT, but it is TCT in L. viridis and Z. rubens. Cameron et al. [24] found that anticodon changes in trnS2 (AGN) (GCT $\rightarrow$ TCT) must have occurred in the common ancestor of the insect clade Ischnocera, which was consistent with its phylogeny of lice. Similarly, this may constitute a kind of "rare genomic change" [25] in nemerteans and be a synapomorphy of Lineidae. 


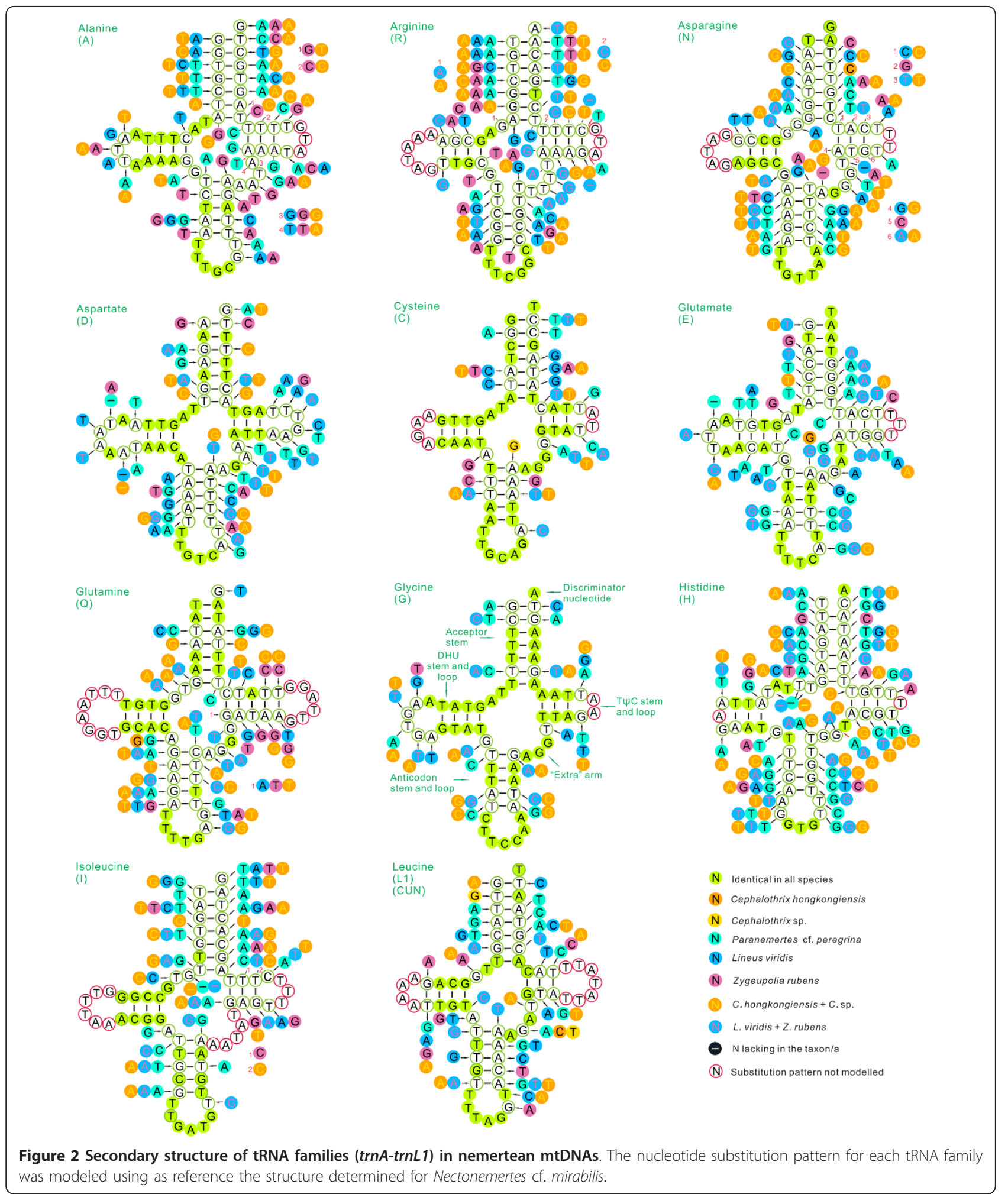

As in all other metazoan mtDNAs sequenced to date, $N$. cf. mirabilis and $Z$. rubens mtDNAs contain genes for both small and large ribosomal subunit RNAs ( $r r n S$ and $r r n L)$. Both genes are encoded by the same strand and are separated by $\operatorname{trn} V$, as in many other metazoans. For $N$. cf. mirabilis and $Z$. rubens, respectively, the lengths of $r r n L / r r n S$ are $1178 / 805 \mathrm{bp}$ and $1248 / 836 \mathrm{bp}$, and the $\mathrm{A}+\mathrm{T}$ contents are $75.5 / 72.4 \%$ and $70.9 / 70.5 \%$. 


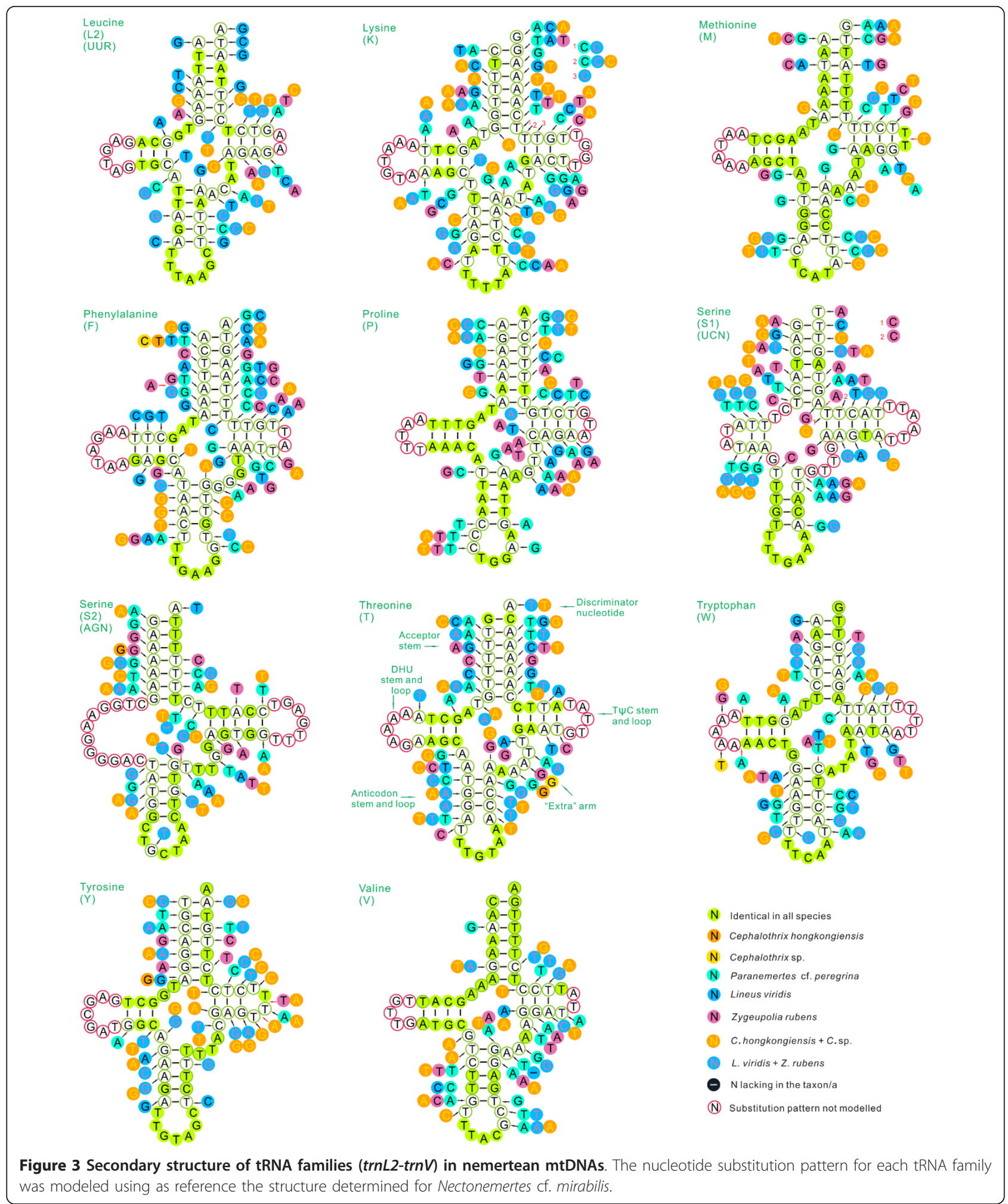

Base composition and codon usage

The mtDNA of many invertebrates is characterized by a composition bias showing high values of $\mathrm{A} \%$ and $\mathrm{T} \%$ over $\mathrm{G} \%$ and $\mathrm{C} \%$. The overall $\mathrm{A}+\mathrm{T}$ content of $N$. cf. mirabilis and Z. rubens (70.3\% and $66.0 \%$, respectively) is consistent with those observed in other nemertean mitochondrial genomes. Though sample size for nemerteans is small, the $A+T$ values appear to be linked in 
Table 3 Summary of multiple alignments of tRNA genes in nemertean mtDNAs

\begin{tabular}{|c|c|c|c|c|}
\hline ALN & amino acid & $\begin{array}{l}\text { alignment } \\
\text { length }\end{array}$ & $\begin{array}{l}\text { identical } \\
\text { positions }\end{array}$ & \%INUC \\
\hline $\operatorname{trn} A$ & Alanine & 72 & 21 & 29.17 \\
\hline $\operatorname{trn} C$ & Cysteine & 66 & 39 & 59.09 \\
\hline $\operatorname{trn} D$ & Aspartate & 66 & 26 & 39.39 \\
\hline $\operatorname{trn} E$ & Glutamate & 65 & 27 & 41.54 \\
\hline $\operatorname{trnF}$ & Phenylalanine & 68 & 22 & 32.35 \\
\hline $\operatorname{trnG}$ & Glycine & 67 & 39 & 58.21 \\
\hline $\operatorname{trnH}$ & Histidine & 67 & 25 & 37.31 \\
\hline $\operatorname{trnl}$ & Isoleucine & 72 & 28 & 38.89 \\
\hline trnk & Lysine & 73 & 23 & 31.51 \\
\hline $\operatorname{trnL} 1$ & Leucine (CUN) & 69 & 21 & 30.43 \\
\hline $\operatorname{trn} L 2$ & Leucine (UUR) & 68 & 28 & 41.18 \\
\hline $\operatorname{trn} M$ & Methionine & 66 & 38 & 57.58 \\
\hline $\operatorname{trnN}$ & Asparagine & 69 & 20 & 28.99 \\
\hline $\operatorname{trn} P^{a}$ & Proline & 67 & 24 & 35.82 \\
\hline $\operatorname{trn} Q$ & Glutamine & 70 & 28 & 40.00 \\
\hline $\operatorname{trn} R$ & Arginine & 67 & 16 & 23.88 \\
\hline trns1 & Serine (UCN) & 71 & 23 & 32.39 \\
\hline $\operatorname{trnS2}$ & Serine (AGN) & 73 & 30 & 41.10 \\
\hline $\operatorname{trn} T^{a}$ & Threonine & 71 & 23 & 32.39 \\
\hline $\operatorname{trnV}$ & Valine & 69 & 33 & 47.83 \\
\hline $\operatorname{trnW}$ & Tryptophan & 70 & 27 & 38.57 \\
\hline $\operatorname{trn} Y$ & Tyrosine & 68 & 32 & 47.06 \\
\hline
\end{tabular}

ALN, alignment name; \%INUC, percent of identical nucleotides agenes on the $L$ strand

less (e.g., genus - e.g., Cephalothrix sp./C. hongkongiensis), as well as in more inclusive taxa (e.g., order - e.g., $P$. cf. peregrina/N. cf. mirabilis; L. viridis/Z. rubens) (Table 2). This might indicate a phylogenetic signal in nemerteans.

Another feature of metazoan mtDNAs is asymmetry in nucleotide composition between the two strands, with one being rich in $\mathrm{A}$ and $\mathrm{C}$, and the other being rich in $\mathrm{T}$ and $\mathrm{G}$ [26]. This asymmetry also is evident in the two nemertean mtDNA genomes here, with the genes encoded on the coding strand showing a strong bias toward $\mathrm{T}$ over $\mathrm{A}$ and toward $\mathrm{G}$ over $\mathrm{C}$, as seen in the four other nemerteans, which have similar skewnesses (Table 2; Figure 4). This situation is common for mitochondrial genomes [26] and may be due to the presence of asymmetric patterns of mutational changes between strands $[27,28]$, and has been related with nucleotide deamination of DNA while transiently single-stranded during replication (this is not without controversy [29]) and/or transcription [30]. The relative importance of the two contributing processes (i. e., transcription vs. replication) remains to be assessed.
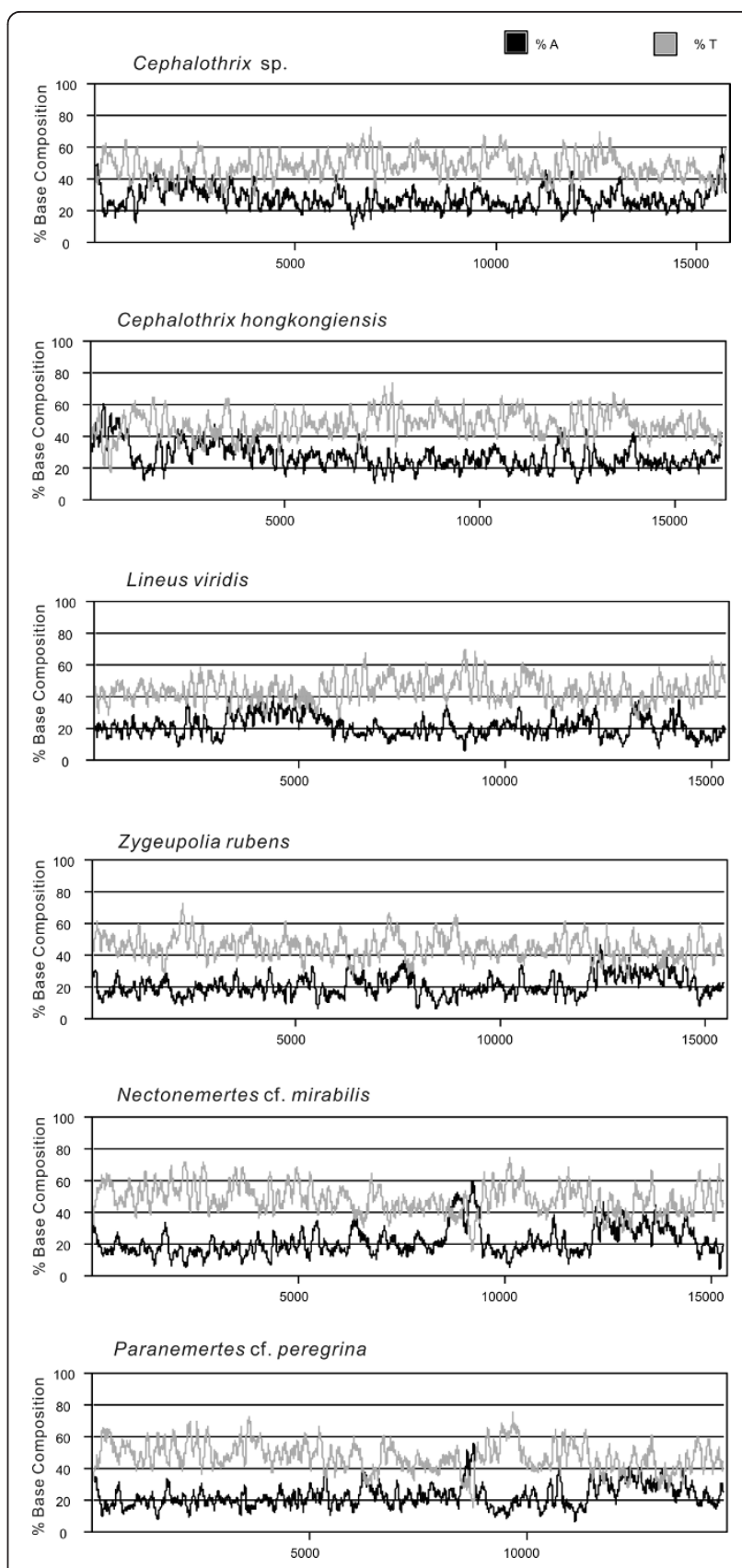

Figure 4 Graphical representation of the percentage of $A$ (black) and T (gray) across the whole mtDNA segment of six nemertean species (Accelrys). Y-axis values represent nucleotide $\%$, calculated with a 100-bp sliding window using the program MacVector ${ }^{\circledR} 7.2 .3$; $x$-axis values represent the nucleotide positions corresponding to the linearized genome.

We follow the pattern of [2] for displaying codon family abundance and relative synonymous codon usage (RSCU) for available nemertean protein-coding genes (Figures 5 and 6). To avoid bias due to incomplete stop codons, all stop codons are excluded from the analysis. The six nemertean mtDNAs use similar total numbers 

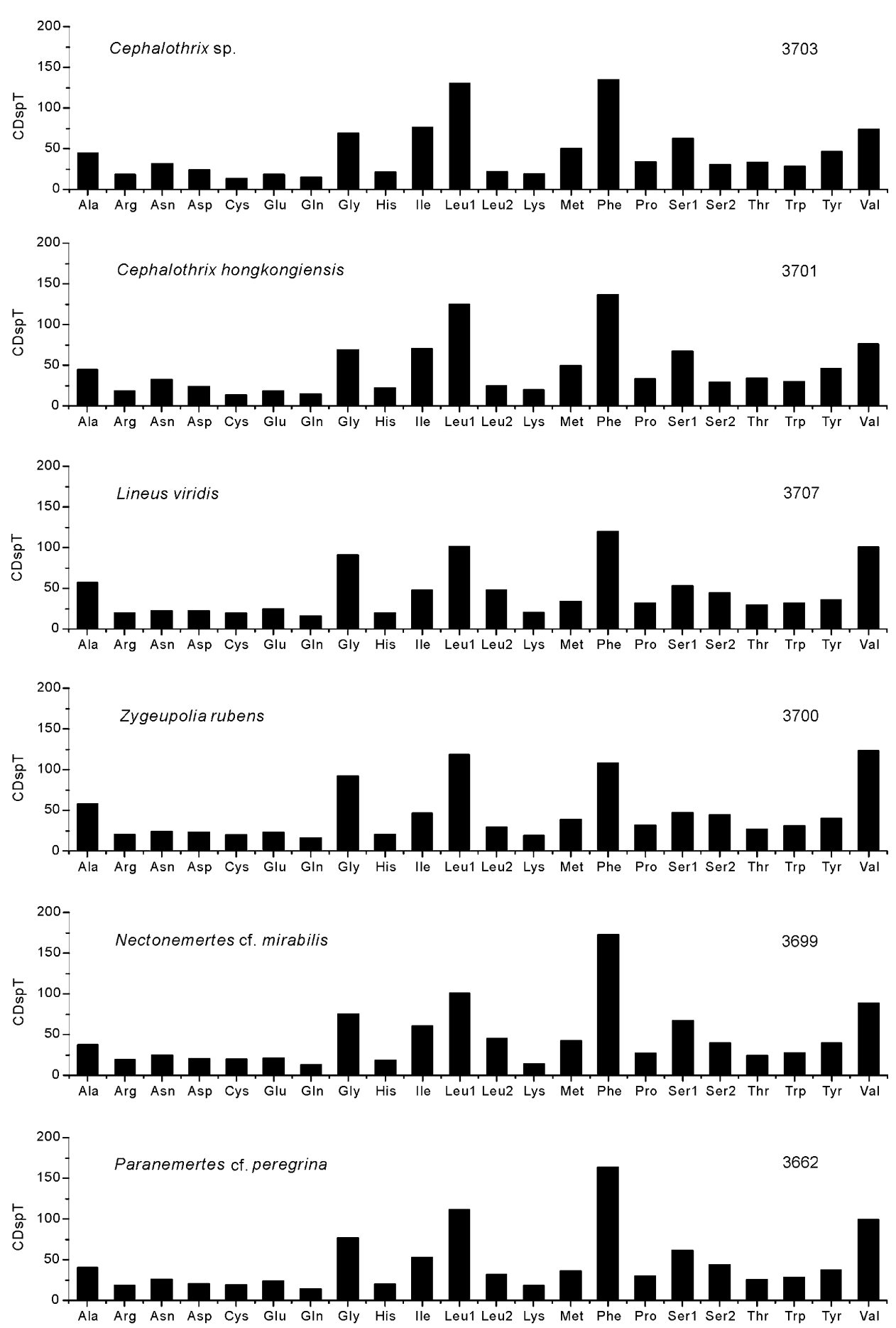

Figure 5 Codon distribution in nemertean mtDNAs. CDspT, number of codons per thousands codons. Numbers to the right refer to the total number of codons.

of non-stop codons (CDs), ranging from 3662 in $P$. cf. peregrina to 3707 in $L$. viridis. The codon families reveal a consistent pattern among the six nemertean species: the families with at least $50 \mathrm{CDs}$ per thousand CDs
(Leu1, Ile, Phe, Gly, Val) encompass an average $48.78 \%$ $\pm 1.33 \%$ of all CDs (Figure 5), with CDs rich in $\mathrm{A}+\mathrm{T}$ favored over synonymous CDs of lower $\mathrm{A}+\mathrm{T}$ content (Figure 6). For instance, the TTA codon accounts for a 


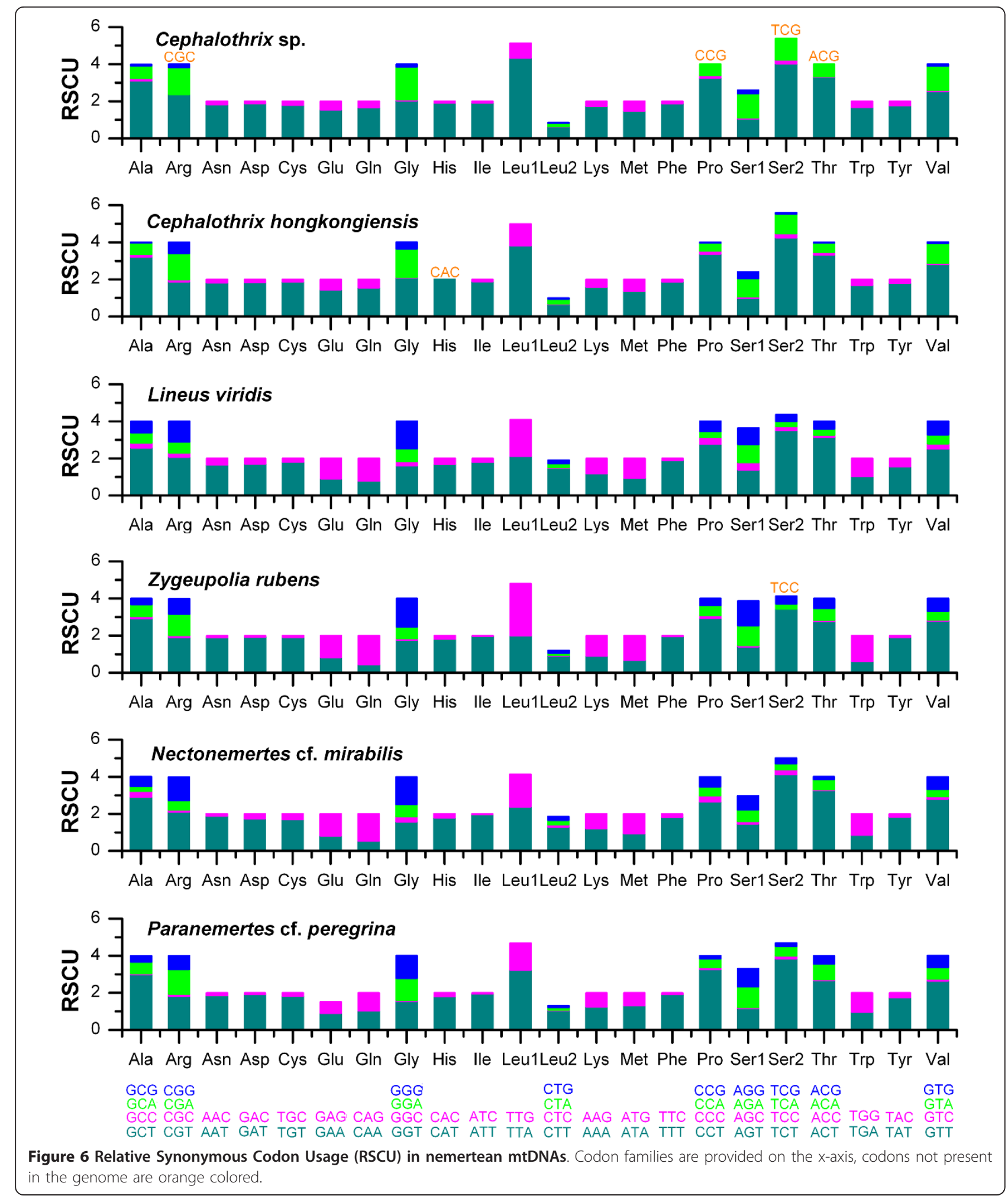

large majority of CDs in the Leu1 family. Whereas representation of the Leu1 (average $=77.3 \pm 7.3 \%$ ) and Leu2 (average $=22.7 \pm 7.3 \%$ ) codon families in nemertean protein-coding genes differs greatly, that of Ser 1 (average $=60.8 \pm 7.3 \%)$ and Ser2 (average $=39.2 \pm$ $7.3 \%)$ is less extreme.

The invertebrate mitochondrial genome codes for 62 amino-acid codons [10]. As pointed out for Lepidoptera 
[2], the total number of codons used seems to be linked to the $\mathrm{A}+\mathrm{T}$ content, which is the case among the six nemertean genomes analyzed. Thus, Cephalothrix sp. mtDNA has the highest $(\mathrm{A}+\mathrm{T}) \%$ content (see Table 2$)$ and uses only 58 codons, never using the four codons rich in G + C (TCG, CGC, ACG, CGC) (Figure 6). Lineus viridis mtDNA uses all 62 codons and has the lowest $\mathrm{A}+\mathrm{T} \%$ among known nemertean genomes.

The abundance of the four amino acid residues - Leu, Ile, Phe and Ser - is typical for invertebrate membrane proteins $[2,31]$, and they account here for more than $46.70 \%$ (average $\mathrm{A}+\mathrm{T}=50.14 \pm 2.70 \%$ ) of residues comprising the 13 mitochondrial proteins. The Leu and Ile amino acids share hydrophobic lateral chains.

Two- and four-fold degenerate codon usage was similarly biased, with $\mathrm{A} / \mathrm{T}$ favored over $\mathrm{G} / \mathrm{C}$ in the third position (Figure 6) and in agreement with the AT-bias of protein-coding genes. Since the nemertean mitochondrial genome is AT-rich (Table 2), it can be expected that codons ending in $\mathrm{A}$ or $\mathrm{T}$ will predominate. From the overall RSCU values, it could be assumed that compositional constraints are the factor in shaping variation in codon usage among the genes in these mitochondrial genomes.

\section{Non-coding regions}

Metazoan mtDNAs usually have lengthy non-coding regions varying in size from $\sim 100 \mathrm{bp}$ to $>20 \mathrm{kbp}$ [32,33]. The mtDNAs of $N$. cf. mirabilis and $Z$. rubens contain a large number of unassigned nucleotides. There are 23 non-coding regions, with up to $855 \mathrm{nts}$, found throughout the $N$. cf. mirabilis mitochondrial genome. The AT-rich region located between the nad3 and $\operatorname{trnS} 2$ genes accounts for $838 \mathrm{nts}$ and its AT content is $81.5 \%$, which is higher than the remainder of the genome. Zygeupolia rubens has up to 879 non-coding nts distributed in 15 regions. The $\mathrm{AT}$-rich region located between trn W and trnS2 genes is $702 \mathrm{nts}$ and has an AT content of $74.9 \%$, which also is higher than the remainder of the genome.

In most metazoan mtDNAs, the largest non-coding region is thought to contain signals for replication and transcription, and is thus referred to as the control region [11]. The non-coding region has an increased AT composition, a characteristic typically used to identify origins of replication [10]. As in mtDNA genomes of other nemerteans, the AT-rich regions of $N$. cf. mirabilis and $Z$. rubens mtDNAs have the potential to form secondary structures such as stems and loops (Figure 7), which are thought to play an important role in the early stages of the replication and transcription process $[34,35]$. Additionally, the AT-rich region in mtDNA of $N$. cf. mirabilis contains the tandemly repeated sequences

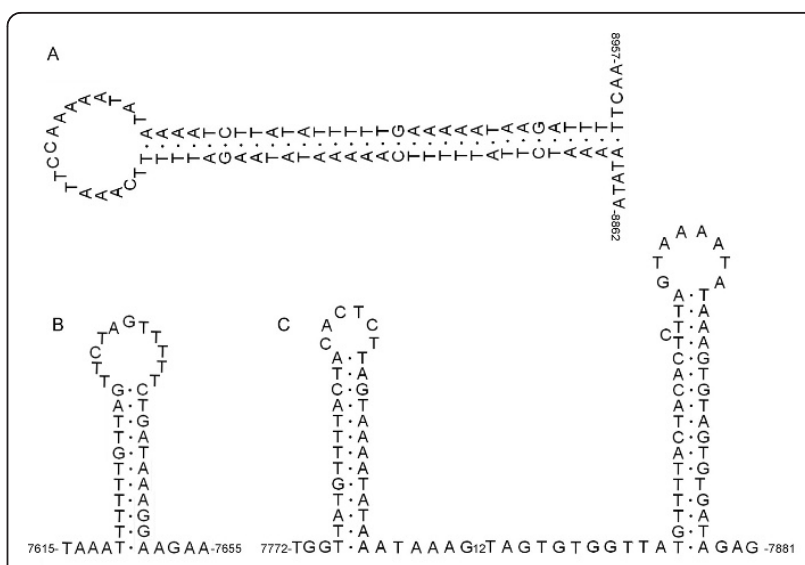

Figure 7 Secondary structures predicted for the non-coding regions in the mitochondrial genome of two nemerteans. (A) Nectonemertes cf. mirabilis, AT-rich non-coding region between genes trnW and trnS2; (B, C) Zygeupolia rubens, AT-rich non-coding region between genes nad3 and trns2.

(AAAAATATAAGATTTTTCAAATTCCAAAAATATAAAAT $)_{3},(\text { TTTTG })_{10}$, $(\text { TTTTTC })_{7}$, and several $(\text { A })_{n}$ and $(\mathrm{T})_{\mathrm{n}}$ homopolymer tracts. In mtDNAs of $Z$. rubens, we found the tandemly repeated sequences (GGGGGGGGGGGTAGTGTGGTTATGTTTTACTACACTCTTAGTAAAATATAAA) $_{2}$, (TTTTTTG) $)_{10}$, and (TTTTTTTTA $)_{6}$. Similar tandem repeat units within the largest non-coding regions also were found in the nemerteans Cephalothrix sp. [8], and C. hongkongiensis [6]. Tandem repeats are common within the control region of animal mtDNAs [34] and might be associated with regulatory mechanisms and recombination hot spots, and they might be the result of replication slippage events [36]. The high AT content and the predicted secondary structures of the AT-rich non-coding region of the $N$. cf. mirabilis and $Z$. rubens mtDNAs suggest that this region most likely contains the control region, though the control region in invertebrates, unlike that of vertebrates, is not well characterized and lacks discrete and conserved sequence blocks used in identification [37]. The nemertean mtDNA sequences examined here had multiple non-coding regions throughout their genomes. However, the location of the largest non-coding region is not conserved, and there is no obvious conservation of size (e.g., $[6,8]$ ), nucleotide identities or potential secondary structures for the nemertean non-coding regions.

\section{Gene order comparison}

Gene arrangements of the animal mitochondrial genome usually remain stable over long periods of evolutionary time, especially for protein-coding genes [10]. With some exceptions, mitochondrial gene order is relatively stable within major groups, and more variable between 
them [14]. This is the case for available nemertean mtDNA genomes, with mitochondrial genes transcribed from the same strand except for trnP and trnT. Among the three species of Cephalothrix (C. hongkongiensis, $C$. sp. and C. rufifrons), the gene order is identical for two but that of $C$. rufifrons differs from them. The two hoplonemertean species ( $P$. cf. peregrina, $N$. cf. mirabilis) are identical to each other in gene order, as is the case for the two heteronemerteans (Z. rubens, L. viridis). The hoplo- and the heteronemertean species differ only by a translocation of the gene block S2/nad 2 but they differ significantly from the three Cephalothrix species in the positions of atp $8, n a d 6, n a d 2$ and several tRNAs. The highest number of common intervals (1124) is between hoplo- and heteronemerteans, as indicated by results from CREx [38].

We use two different gene sets, "all genes" and "nontRNA genes" to compare the mt gene orders of nemerteans to the proposed ground pattern of Bilateria [39] and to mitochondrial gene orders of various lophotrochozoans: Terebratulina retusa (Brachiopoda) [40], Katharina tunicata (Mollusca)[14], Phoronis psammophila (Phoronida) [41], Perionyx excavatus (Annelida) [42], Urechis caupo (Annelida) [43] and Sipunculus nudus (Annelida)[44]. For the "all genes" set, all nemerteans share the adjacency nad4L/nad4 with the ground pattern of Bilateria and with the selected species (Figure 8). Nemerteans share the adjacencies $r r n S / V / r r n L$ with Bilateria and the other species except $U$. caupo. The adjacency $\mathrm{H} /$ nad5 is shared by nemerteans and the selected species. Based on both gene sets, the heteroand hoplonemerteans share the adjacency nad6/cob with K. tunicata [14], P. psammophila [41], P. excavatus [42], $U$. caupo [43], and S. nudus [44] and they share the adjacency atp8/atp 6 with $T$. retusa, $K$. tunicata and the putative ground pattern of Bilateria (Figure 8; Additional file 1: Figure S1). These adjacencies may be a common plesiomorphic feature of Lophotrochozoa, such as Mollusca, Brachiopoda, and also Arthropoda mitochondrial genomes (e.g., [10]; [44]). However, neither of the latter two adjacencies is present in two Cephalothrix species, nor in the bryozoan Flustrellidra hispida [45].

In addition to visual comparison of genome maps, we analyzed gene order data with CREx [38], determining the number of common intervals. As shown in Table 4, the nemerteans share the highest number of common intervals $(154,184,212)$ with $K$. tunicata and with $P$. psammophila (but this is a partial mitochondrial genome), while the lowest number was obtained in comparison with $U$. caupo $(28,18,18)$. Although not significant, nemerteans and T. retusa, $K$. tunicata, and $P$. excavatus yield the highest numbers $(18-20)$ in comparison with the putative bilaterian ground pattern.
Figure 8 shows tRNA genes change relative position much faster than the protein-coding and rRNA genes, as reported from previous studies (e.g., $[46,47]$ ).

Excluding tRNAs, the gene order of heteronemerteans is identical to that of $T$. retusa [40] and some gastropods, e. g., Conus textile [48], Ilyanassa obsoleta [49], Thais clavigera [37] and Lophiotoma cerithiformis [50]. Other molluscs, like the polyplacophoran $K$. tunicata [14], the gastropod Haliotis rubra [51] and the cephalopod Octopus vulgaris [52] show a similar gene order, but are distinguished by a large inversion of about half the mt genome (Additional file 1: Figure S1). Without tRNAs, heteronemerteans and T. retusa, which has the same gene order, share the greatest number of possible common intervals (204) (Table 4), and both share the greatest number (52) with the putative bilaterian ground pattern.

We also determined breakpoints and reversal distances between these taxa with the two gene sets (Additional files 2, 3: Tables S1, S2). For "all genes", hetero- and hoplonemerteans share the same breakpoint distance (31) and the same reversal distance (28) (whereas palaeonemerteans are 32 and 31, respectively) with respect to the putative bilaterian ground pattern. Heteronemerteans have the lowest values among the nemerteans when tRNAs are excluded from the analysis. These comparisons with the putative bilaterian ground pattern and with other lophotrochozoans gene orders (especially when excluding tRNAs), suggest that the heteronemertean gene order is likely to be closest to the ancestral mitochondrial gene order of Nemertea. This is in agreement with a previous study [7].

\section{Phylogenetic analysis}

We performed a phylogenetic analysis based on nucleotide sequences of protein-coding genes to better understand relationships within the Nemertea. The phylogenetic tree in Figure 9, reconstructed by maximum likelihood and Bayesian analyses, indicates that similar gene arrangements reflect close phylogenetic affinity. This supports previous hypotheses that Hoplonemertea and Heteronemertea are sister taxa (e.g., [53-55]). However, a phylogenetic analysis based on amino acid sequences (data not shown) suggests Hoplonemertea as sister group to Palaeonemertea. This contradicts many but not all previous analyses (e.g., [55]). We consider it unsupported by our data, given the low Bayesian posterior probability $(0.61)$ for this clade. This suggests, however, that amino acid sequence data deserve continued attention in future analyses with new, additional data.

\section{Conclusion}

To date, complete or nearly complete mtDNA sequences have been determined for seven nemerteans, a very small sampling compared to those available for vertebrates or 


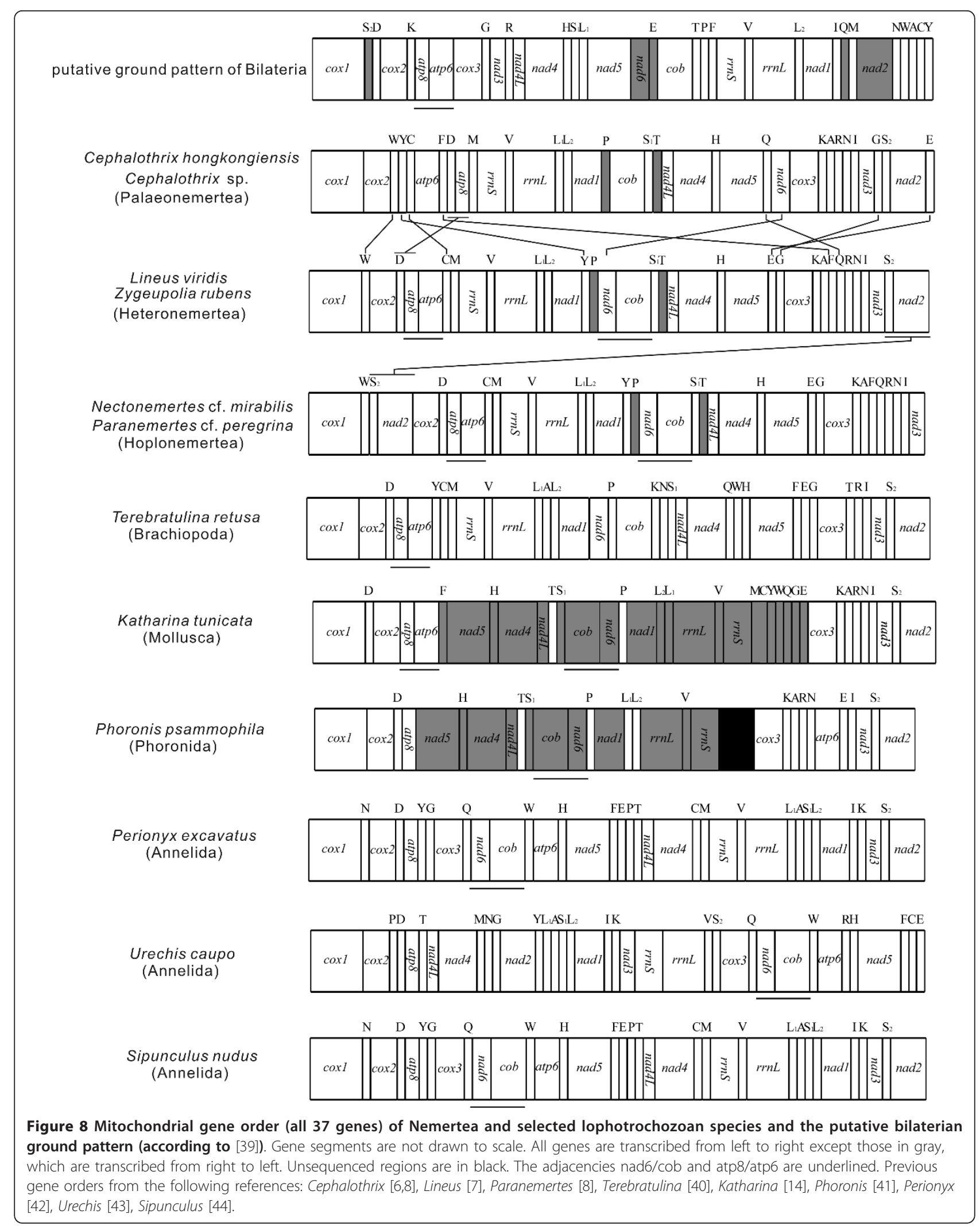


Table 4 Pairwise common interval distance matrix of mitochondrial gene orders of nemerteans, the putative bilaterian ground pattern and six other lophotrochozoans *

\begin{tabular}{|c|c|c|c|c|c|c|c|c|c|c|}
\hline Common interval & B & $P$ & $\mathrm{H}$ & $\mathrm{H}$ & $\operatorname{Tr}$ & $\mathrm{Kt}$ & Uc & Sn & $\mathrm{Pe}$ & $\mathrm{Pp}$ \\
\hline Bilaterian ground pattern (B) & $204 \backslash 1326$ & 18 & 20 & 20 & 18 & 20 & 12 & 14 & 20 & 12 \\
\hline Palaeonemertean (P) & 44 & $204 \backslash 1326$ & 108 & 112 & 40 & 154 & 28 & 42 & 38 & 142 \\
\hline Heteronemertean $(\mathrm{H})$ & 52 & 86 & $204 \backslash 1326$ & 1124 & 68 & 184 & 18 & 64 & 56 & 230 \\
\hline Hoplonemertean $(\mathrm{H})$ & 44 & 72 & 178 & $204 \backslash 1326$ & 84 & 212 & 18 & 68 & 66 & 254 \\
\hline Terebratulina retusa $(\mathrm{Tr})$ & 52 & 86 & 204 & 178 & $204 \backslash 1326$ & 128 & 20 & 74 & 82 & 110 \\
\hline Katharina tunicata $(\mathrm{Kt})$ & 48 & 56 & 106 & 94 & 106 & $204 \backslash 1326$ & 20 & 62 & 64 & 266 \\
\hline Urechis caupo (Uc) & 16 & 8 & 14 & 8 & 14 & 34 & $204 \backslash 1326$ & 54 & 144 & 22 \\
\hline Sipunculus nudus (Sn) & 34 & 12 & 22 & 16 & 22 & 26 & 26 & $204 \backslash 1326$ & 158 & 38 \\
\hline$\overline{\text { Perionyx excavatus }(\mathrm{Pe})^{a}}$ & 28 & 24 & 40 & 32 & 40 & 48 & 44 & 60 & $204 \backslash 1254$ & 44 \\
\hline Phoronis psammophila (Pp) & 40 & 48 & 84 & 76 & 84 & 98 & 22 & 24 & 38 & $204 \backslash 864$ \\
\hline
\end{tabular}

*bold numbers represent pairwise common interval distances between mitochondrial gene orders (37 genes in total), while italic numbers represent pairwise common interval distances between mt gene orders without tRNAs (15 genes in total)

alacks $\operatorname{trn} R$

blacks several tRNAs

arthropods. The two new mtDNA genomes, for Nectonemertes cf. mirabilis and Zygeupolia rubens, share substantial similarity with those of other nemertean mitochondrial genomes, and gene content and $\mathrm{A}+\mathrm{T}$ richness is similar to those common for animal mtDNAs.

There is strong skew in the distribution of nucleotides between the two strands.

The evolution of nemertean tRNAs seems to have been variable both in terms of sequence conservation and nucleotide substitution processes. The presence of full and hemi-cbcs characterizing taxa at different taxonomic levels may indicate the potential phylogenetic value of tRNA sequences.

Nemertean mtDNAs are punctuated by non-coding portions highly variable in size. Among them, the ATrich non-coding region, which appears to be a fast-evolving genomic region characterized by short to mediumsize repeated motifs/AT-rich patterns, may be associated with the initiation of replication or transcription.

Phylogenetic analysis supports the close phylogenetic affinities in nemerteans one might infer from similarities in gene arrangements, with Hetero- and Hoplonemerteans as sister-clades. Gene order analysis suggests that the heteronemertean pattern most closely resembles the likely ancestral condition among nemerteans, which is counterintuitive in light of the phylogenetic analysis. Confidence that we understand evolution of the nemertean mitochondrial genome is likely to require investigating many more nemertean mtDNAs, especially a full representation of palaeonemertean diversity.

\section{Methods}

DNA extraction, PCR and sequencing

Specimens were collected off Point Conception, California (Nectonemertes cf. mirabilis) and at Fort Pierce,
Florida (Zygeupolia rubens), USA. We use the "cf." qualifier to confer reasonable caution that the Pacific worm traditionally designated $N$. mirabilis (see [56]) is conspecific with its presumed cognate originally described from the North Atlantic Ocean. Samples were frozen in liquid nitrogen and preserved in RNAlater. Total DNA was extracted from a single individual specimen using the DNeasy Tissue Kit following the manufacturer's protocol (Qiagen, Valencia, CA, USA). PCR primers used for amplification are listed in Table 5. Preliminary nemertean-specific primers (N12SF, N16SR, NCOX2R) were designed based on sequence alignment of four mitochondrial genome sequences (Cephalothrix hongkongiensis, Cephalothrix. sp., Lineus viridis, and Paranemertes cf. peregrina) retrieved from Genbank. For both species, the partial regions $r r n S-r r n L$ and $r r n L-c o b$

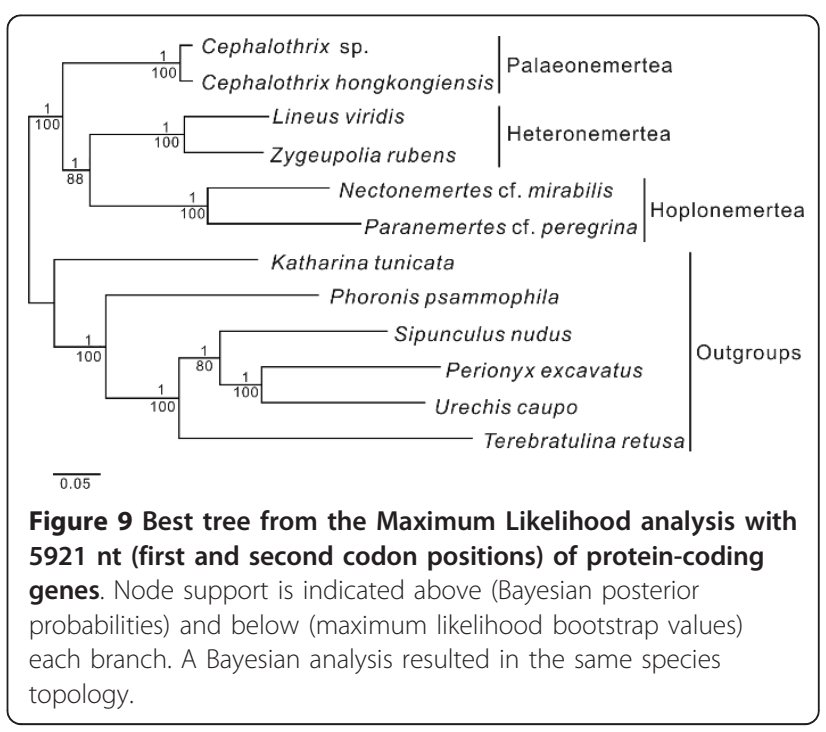


Table 5 PCR primers used to amplify the mitochondrial genomes of Nectonemertes cf. mirabilis

\begin{tabular}{|c|c|c|}
\hline Primer name & Sequence $\left(5^{\prime} \rightarrow 3^{\prime}\right)$ & References \\
\hline \multicolumn{3}{|l|}{ Universal } \\
\hline \multicolumn{3}{|l|}{$r r n S-r r n L$} \\
\hline N12SF & TGTGCCAGCTTCCGCGGTTATAC & Present study \\
\hline N16SR & ACGCTGTTATCCCTATGGTA & Present study \\
\hline \multicolumn{3}{|l|}{$r r n L-c o b$} \\
\hline 16SarL & CGCCTGTTTATCAAAAACAT & [57] \\
\hline CytbR & GCRTAWGCRAAWARRARTAYCAYTCWGG & [58] \\
\hline \multicolumn{3}{|c|}{ Nectonemertes cf. mirabilis } \\
\hline \multicolumn{3}{|l|}{$\operatorname{cox} 1$} \\
\hline LCO-1490 & GGTCAACAAATCATAAAGATATTGG & [59] \\
\hline HCO-2198 & TAAACTTCAGGGTGACCAAAAAATCA & [59] \\
\hline \multicolumn{3}{|l|}{$\cos 3$} \\
\hline $\operatorname{cox} 3 \mathrm{~F}$ & TGCGWTGAGGWATAATTTTATTTATT & [8] \\
\hline $\operatorname{cox} 3 R$ & ACCAAGCAGCTGCTTCAAAACCAAA & {$[8]$} \\
\hline \multicolumn{3}{|l|}{$\operatorname{cob}-\cos 3$} \\
\hline $\mathrm{Nm}$ cobF & TCGGTGGATAATGCTACTTTG & Present study \\
\hline $\mathrm{Nm} \operatorname{COX} 3 \mathrm{R}$ & ACCAGAAGCCAACAATACAGC & Present study \\
\hline \multicolumn{3}{|l|}{$\cos 3-\cos 1$} \\
\hline $\mathrm{Nm}$ COX3F & TGTTGGCTTCTGGTGTTAGTG & Present study \\
\hline $\mathrm{Nm} \operatorname{COX} 1 \mathrm{R}$ & GAGCCTCTITCAACAACAGCA & Present study \\
\hline \multicolumn{3}{|l|}{ cox1-rrns } \\
\hline NmCOX1F & AATCTGGTCTGGGTTGGTTGGCACTGCGTTA & Present study \\
\hline $\mathrm{Nm12SR}$ & GACTCCCCTGAAAGGACATAAAACACCG & Present study \\
\hline \multicolumn{3}{|c|}{ Zygeupolia rubens } \\
\hline \multicolumn{3}{|l|}{ cob-cox3 } \\
\hline Zrcob F & CTTGGGTTGTTGCTGTTG & Present study \\
\hline $\mathrm{ZrCOX3R}$ & GTTGAACCATAAATCCCATC & Present study \\
\hline \multicolumn{3}{|l|}{$\cos 3-\cos 1$} \\
\hline $\operatorname{cox} 3 \mathrm{~F}$ & TGCGWTGAGGWATAATTTTATTTATT & {$[8]$} \\
\hline ZrCOX1R & GAGCCTCTITCAACAACAGCA & Present study \\
\hline \multicolumn{3}{|l|}{$\cos 1-\cos 2$} \\
\hline LCO-1490 & GGTCAACAAATCATAAAGATATTGG & {$[59]$} \\
\hline NCOX2R & AAAGAATGATTWGCWCCAC & Present study \\
\hline \multicolumn{3}{|l|}{ cox2-rrns } \\
\hline $\mathrm{ZrCOX} 2 \mathrm{~F}$ & TTTGGCTTTACCTTCTTTGC & Present study \\
\hline Zr12SR & AAATAAGACACCGCCAAGT & Present study \\
\hline
\end{tabular}

were amplified first. For $N$. cf. mirabilis, partial fragments of $\operatorname{cox} 1$ and $\operatorname{cox} 3$ genes were amplified using universal PCR primers LCO-2198/HCO-1490, cox3F/cox3R ([59]; [9]). These sequences were used to design specific primers to amplify the remaining mitochondrial genome fragments (cob-cox3, cox3-cox 1 and $\operatorname{cox} 1$-rrnS). For $Z$. rubens, the fragment of $\operatorname{cox} 1-\operatorname{cox} 2$ was amplified using the universal primer LCO-2198 [59] combined with the specific primer NCOX2R. Based on sequences obtained, specific primers were designed to amplify the regions
cox2-rrnS, cob-cox3 and cox3-cox1. Conventional PCR and long PCR, cloning, and sequencing were performed as described in Chen et al. [6,8].

\section{Sequence assemblage and annotation}

All sequences were checked and assembled by visual inspection using the program SeqMan (DNA star, Madison, WI, USA). Protein-coding genes and ribosomal RNA genes were identified by their similarity to previously reported mitochondrial genomes of Cephalothrix 
hongkongiensis (GenBank \#NC_012821), C. rufifrons (EF140788), Cephalothrix sp. (NC_014869), Lineus viridis (NC_012889), and Paranemertes cf. peregrina (NC_014865). Most tRNAs were identified by using invertebrate mitochondrial codon predictors with tRNAscan-SE 1.21 [60]. The remaining tRNA genes were found by inspecting sequences for tRNA-like secondary structures and anticodons. Multiple alignments of tRNA genes were produced, and the percent of identical nucleotides (\%INUC) was calculated for six nemertean tRNA sequences. Secondary structures within the non-coding fragments were visualized by using RnaViz 2.0 [61], and the mitochondrial genome was visualized using CGView [62].

\section{Genomics analysis}

Nucleotide composition and Relative Synonymous Codon Usage (RSCU) values were analyzed with MEGA 4.0 [63]. AT- and GC-skew were determined by using the formulation of [26].

\section{Gene order comparisons}

Gene orders were compared between all available nemerteans (see above), the putative bilaterian ground pattern [39], Terebratulina retusa [40], Katharina tunicata [14], Phoronis psammophila [41], Perionyx excavatus [42], Urechis caupo [43] and Sipunculus nudus [44].

The gene orders were compared with two different gene sets: "all genes" included all 37 mitochondrial genes, whereas "non-tRNA genes" included only the two ribosomal genes and the 13 protein-coding genes.

The differences between gene orders were analysed using common intervals [38], breakpoints [64] and reversal distances [65] implemented in the CREx tool [38].

\section{Phylogenetic analysis}

The currently available near-complete and complete mitochondrial nemertean genome data (Cephalothrix sp., C. hongkongiensis, L. viridis, and P. cf. peregrina, but not the partial genome sequence of $C$. rufifrons) were combined with sequences from this study for phylogenomic analyses. The nucleic acids for all 12 protein-coding genes (except atp8, which is shortest and least conserved between the taxa) were aligned using Clustal $X$ [66] with the default settings. Ambiguously aligned portions of both alignments were excluded using Gblocks version 0.91b [67] with default block parameters. We also excluded third codon positions because of the fast substitution rate. The total number of nucleotides used for the phylogenetic analysis was 5921.

Based on previous studies of metazoan relationships (e.g., [68-73]), the following six species were selected as outgroups: a mollusc (Katharina tunicata), a brachiopod
(Terebratalia retusa), a phoronid (Phoronis psammophila), and three annelids (Perionyx excavatus, Sipunculus nudus and Urechis caupo).

Phylogenetic trees were estimated under maximum likelihood (ML) and Bayesian inference (BI). ML analysis on the combined nucleotide dataset alignments was performed in RAxML 7.2.7 [74,75] available on the CIPRES web portal [76] with the GTRGAMMA substitution model. Support was estimated by performing 1000 bootstrap replicates. BI analysis was performed with MrBayes version 3.0b4 [77,78], using GTR + I + G model, a best-fit model selected by MrModeltest v2.2 [79] following the Akaike information criterion (AIC). The Monte Carlo Markov chain (MCMC) length was 1,000,000 generations and sampled every 100 generations. The first 2500 trees from each run were discarded as a burn-in.

Amino acid sequences were aligned with both Clustal $\mathrm{X}[66]$ and MAFFT using the G-INS-i strategy [80]. BI analyses were performed with MrBayes version 3.0b4 $[77,78]$ with the mtRev + I + G model, selected by Protest 10.2 [81] as optimal. We also implemented the CAT + GTR model in PhyloBayes 3 [82]. The ML analysis was carried out with RAxML 7.2.7 [74,75] with CAT model.

The mitochondrial genome sequences of $N$. cf. mirabilis and Z. rubens are deposited in GenBank under the accession numbers HQ997772 and HQ997773.

\section{Additional material}

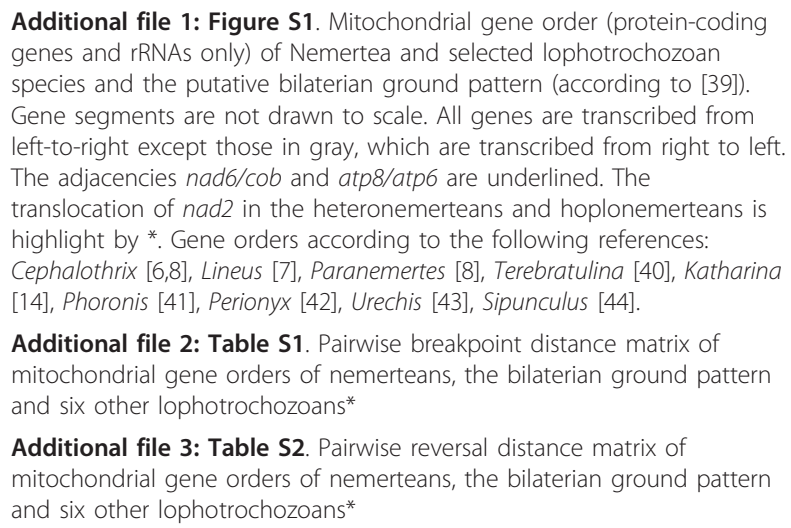

Additional file 2: Table S1. Pairwise breakpoint distance matrix of mitochondrial gene orders of nemerteans, the bilaterian ground pattern and six other lophotrochozoans*

Additional file 3: Table S2. Pairwise reversal distance matrix of mitochondrial gene orders of nemerteans, the bilaterian ground pattern and six other lophotrochozoans*

\section{Abbreviations}

atp6 and atp8: ATP synthase subunits 6 and 8 ; cob: cytochrome $b$; cox 1-3: subunits I-III of cytochrome c oxidase; nad1-6 and nad4L: NADH dehydrogenase subunits 1-6 and $4 \mathrm{~L} ; \mathrm{rrnL}$ and $r r n S$ : the large and small subunits of ribosomal RNA; $\operatorname{trn} X$ : genes encoding for transfer RNA molecules with corresponding amino acids denoted by the one-letter code and codon indicated in parentheses (xxx) when necessary; DHU: dihydrouridine loop; MtDNA: mitochondrial DNA; NC: non-coding region; PCR: polymerase chain reaction; Kb: kilobase; bp: base pair; nt: nucleotide; nucleotide symbol combination: $R=A / G ; Y=C / T ; W=A / T ; K=G / T ; N=A / G / C / T$. 


\section{Acknowledgements}

This work was supported by the National Natural Science Foundation of China (to SCS, grant no. 30970333,), the Swedish Research Council (to PS), Smithsonian Institution Scholarly Studies, Research Opportunities, and Marine Science Network awards (to JLN) and represents contribution 878 of the Smithsonian Marine Station at Fort Pierce. JLN is grateful to James Childress (UCSB) and his support from the US National Science Foundation for the opportunity to collect living Nectonemertes cf. mirabilis.

\section{Author details}

'Department of Biological and Environmental Sciences, University of Gothenburg, PO Box 463, SE-405 30 Gothenburg, Sweden. ${ }^{2}$ Institute of Evolution \& Marine Biodiversity, Ocean University of China, 5 Yushan Road, Qingdao 266003, China. ${ }^{3}$ Department of Rheumatology and Inflammation Research, Sahlgrenska Academy, University of Gothenburg, PO Box 480, SE405 30, Sweden. ${ }^{4}$ Department of Invertebrate Zoology, National Museum of Natural History, Smithsonian Institution, Washington, DC 20560-0163, USA.

\section{Authors' contributions}

HXC performed the majority of the molecular experiments and analyzed the data, and drafted the manuscript. SCS supervised the research. PS contributed to the analysis of the data. WCR performed part of the study, and provided technical assistance. JLN collected specimens, conceived, designed the research plan and did significant revisions of the manuscript draft. All authors read and approved the final manuscript.

\section{Competing interests}

The authors declare that they have no competing interests.

Received: 2 May 2011 Accepted: 17 April 2012 Published: 17 April 2012

\section{References}

1. Hu M, Chilton NB, Gasser RB: The mitochondrial genomics of parasitic nematodes of socio-economic importance: recent progress, and implications for population genetics and systematics. Adv Parasitol 2004, 56:133-212.

2. Salvato $\mathrm{P}$, Simonato $\mathrm{M}$, Battisti $\mathrm{A}$, Negrisolo $\mathrm{E}$ : The complete mitochondrial genome of the bag-shelter moth Ochrogaster lunifer (Lepidoptera, Notodontidae). BMC Genomics 2008, 9:331.

3. Boore JL, Brown WM: Big trees from little genomes: mitochondrial gene order as a phylogenetic tool. Curr Opin Genet Dev 1998, 8(6):668-674.

4. Lavrov DV, Brown WM, Boore JL: Phylogenetic position of the Pentastomida and (pan)crustacean relationships. Proc Biol Sci 2004, 271(1538):537-544

5. Kajihara H, Chernyshev AV, Sun SC, Sundberg P, Crandall FB: Checklist of nemertean genera and species published between 1995 and 2007. Spec Diver 2008, 13:245-274.

6. Chen $H X$, Sundberg $P$, Norenburg $J L$, Sun SC: The complete mitochondrial genome of Cephalothrix simula (Iwata) (Nemertea: Palaeonemertea). Gene 2009, 442(1-2):8-17.

7. Podsiadlowski L, Braband A, Struck TH, von Döhren J, Bartolomaeus T: Phylogeny and mitochondrial gene order variation in Lophotrochozoa in the light of new mitogenomic data from Nemertea. BMC Genomics 2009, 10:364.

8. Chen HX, Sundberg P, Wu HY, Sun SC: The mitochondrial genomes of two nemerteans, Cephalothrix sp. (Nemertea: Palaeonemertea) and Paranemertes cf. peregrina (Nemertea: Hoplonemertea). Mol Biol Rep 2011, 38(7):4509-4525.

9. Turbeville JM, Smith DM: The partial mitochondrial genome of the Cephalothrix rufifrons (Nemertea, Palaeonemertea): characterization and implications for the phylogenetic position of Nemertea. Mol Phylogenet Evol 2007, 43(3):1056-1065.

10. Boore JL: Animal mitochondrial genomes. Nucleic Acids Res 1999, 27(8):1767-1780

11. Wolstenholme DR: Animal mitochondrial DNA: structure and evolution. Int Rev Cytol 1992, 141:173-216

12. Ojala D, Merkel C, Gelfand R, Attardi G: The tRNA genes punctuate the reading of genetic information in human mitochondrial DNA. Cell 1980, 22(2 Pt 2):393-403.
13. Montoya J, Gaines GL, Attardi G: The pattern of transcription of the human mitochondrial rRNA genes reveals two overlapping transcription units. Cell 1983, 34(1):151-159.

14. Boore JL, Brown WM: Complete DNA sequence of the mitochondrial genome of the black chiton, Katharina tunicata. Genetics 1994, 138(2):423-443.

15. Kim I, Lee EM, Seol KY, Yun EY, Lee YB, Hwang JS, Jin BR: The mitochondrial genome of the Korean hairstreak, Coreana raphaelis (Lepidoptera: Lycaenidae). Insect Mol Biol 2006, 15(2):217-225.

16. Fenn JD, Cameron SL, Whiting MF: The complete mitochondrial genome sequence of the Mormon cricket (Anabrus simplex: Tettigoniidae: Orthoptera) and an analysis of control region variability. Insect Mol Biol 2007, 16(2):239-252.

17. Lavrov DV, Brown WM, Boore JL: A novel type of RNA editing occurs in the mitochondrial tRNAs of the centipede Lithobius forficatus. Proc Nat Acad Sci USA 2000, 97(25):13738-13742.

18. Macey JR, Larson A, Ananjeva NB, Papenfuss TJ: Replication slippage may cause parallel evolution in the secondary structures of mitochondrial transfer RNAs. Mol Biol Evol 1997, 14(1):30-39.

19. Yamazaki N, Ueshima R, Terrett JA, Yokobori S, Kaifu M, Segawa R, Kobayashi T, Numachi K, Ueda T, Nishikawa K, et al: Evolution of pulmonate gastropod mitochondrial genomes: comparisons of gene organizations of Euhadra, Cepaea and Albinaria and implications of unusual tRNA secondary structures. Genetics 1997, 145(3):749-758.

20. Negrisolo E, Babbucci M, Patarnello T: The mitochondrial genome of the ascalaphid owlfly Libelloides macaronius and comparative evolutionary mitochondriomics of neuropterid insects. BMC Genomics 2011, 12:221.

21. Cannone JJ, Subramanian S, Schnare MN, Collett JR, D'Souza LM, Du Y, Feng B, Lin N, Madabusi LV, Müller KM, et al: The comparative RNA web (CRW) site: an online database of comparative sequence and structure information for ribosomal, intron, and other RNAs. BMC Bioinforma 2002 3:2.

22. Coleman AW: ITS2 is a double-edged tool for eukaryote evolutionary comparisons. Trends Genet 2003, 19(7):370-375.

23. Miya M, Satoh TR, Nishida M: The phylogenetic position of toadfishes (order Batrachoidiformes) in the higher ray-finned fish as inferred from partitioned Bayesian analysis of 102 whole mitochondrial genome sequences. Biol J Linn Soc 2005, 85(3):289-306.

24. Cameron SL, Johnson KP, Whiting MF: The mitochondrial genome of the screamer louse Bothriometopus (Phthiraptera: Ischnocera): Effects of extensive gene rearrangements on the evolution of the genome. J Mol Evol 2007, 65(5):589-604.

25. Rokas A, Holland PW: Rare genomic changes as a tool for phylogenetics. Trends Ecol Evol 2000, 15(11):454-459.

26. Perna NT, Kocher TD: Patterns of nucleotide composition at fourfold degenerate sites of animal mitochondrial genomes. J Mol Evol 1995, 41(3):353-358.

27. Lobry JR: Properties of a general model of DNA evolution under nostrand-bias conditions. J Mol Evol 1995, 40(3):326-330.

28. Sueoka N: Intrastrand parity rules of DNA base composition and usage biases of synonymous codons. J Mol Evol 1995, 40(3):318-325.

29. Bogenhagen DF, Clayton DA: The mitochondrial DNA replication bubble has not burst. Trends Biochem Sci 2003, 28(7):357-360.

30. Hassanin A, Leger N, Deutsch J: Evidence for multiple reversals of asymmetric mutational constraints during the evolution of the mitochondrial genome of Metazoa, and consequences for phylogenetic inferences. Syst Biol 2005, 54(2):277-298.

31. Webster BL, Mackenzie-Dodds JA, Telford MJ, Littlewood DT: The mitochondrial genome of Priapulus caudatus Lamarck (Priapulida: Priapulidae). Gene 2007, 389(1):96-105.

32. Jacobs HT, Elliott DJ, Math VB, Farquharson A: Nucleotide sequence and gene organization of sea urchin mitochondrial DNA. J Mol Biol 1988, 202(2):185-217.

33. Boyce TM, Zwick ME, Aquadro CF: Mitochondrial DNA in the bark weevils: size, structure and heteroplasmy. Genetics 1989, 123(4):825-836.

34. Lunt DH, Whipple LE, Hyman BC: Mitochondrial DNA variable number tandem repeats (VNTRs): utility and problems in molecular ecology. Mol Ecol 1998, 7(11):1441-1455.

35. Wilkinson GS, Chapman AM: Length and sequence variation in evening bat D-loop mtDNA. Genetics 1991, 128(3):607-617. 
36. Kolpakov R, Bana G, Kucherov G: mreps: efficient and flexible detection of tandem repeats in DNA. Nucleic Acids Res 2003, 31(13):3672-3678.

37. Ki J-S, Lee Y-M, Jung S-O, Horiguchi T, Cho H-S, Lee J-S: Mitochondrial genome of Thais clavigera (Mollusca: Gastropoda): Affirmation of the conserved, ancestral gene pattern within the mollusks. Mol Phylogenet Evol 2010, 54:1016-1020.

38. Bernt M, Merkle D, Ramsch K, Fritzsch G, Perseke M, Bernhard D, Schlegel M, Stadler PF, Middendorf M: CREx: inferring genomic rearrangements based on common intervals. Bioinformatics 2007, 23(21):2957-2958.

39. Lavrov DV, Lang BF: Poriferan mtDNA and animal phylogeny based on mitochondrial gene arrangements. Syst Biol 2005, 54(4):651-659.

40. Stechmann A, Schlegel M: Analysis of the complete mitochondrial DNA sequence of the brachiopod Terebratulina retusa places Brachiopoda within the protostomes. P Roy Soc Lond B Bio 1999, 266(1433):2043-2052

41. Helfenbein KG, Boore JL: The mitochondrial genome of Phoronis architecta-comparisons demonstrate that phoronids are lophotrochozoan protostomes. Mol Biol Evol 2004, 21(1):153-157.

42. Kim DW, Lee KS, Jee SH, Seo SB, Park SC, Choo JK: Complete sequence analysis of the mitochondrial genome in the earthworm, Perionyx excavatus. Integr Biosci 2005, 9:A705.

43. Boore JL: Complete mitochondrial genome sequence of Urechis caupo, a representative of the phylum Echiura. BMC Genomics 2004, 5(1):67

44. Mwinyi A, Meyer A, Bleidorn C, Lieb B, Bartolomaeus T, Podsiadlowski L: Mitochondrial genome sequence and gene order of Sipunculus nudus give additional support for an inclusion of Sipuncula into Annelida. BMC Genomics 2009, 10:27.

45. Waeschenbach A, Telford MJ, Porter JS, Littlewood DT: The complete mitochondrial genome of Flustrellidra hispida and the phylogenetic position of Bryozoa among the Metazoa. Mol Phylogenet Evol 2006, 40(1):195-207.

46. Kilpert F, Podsiadlowski L: The complete mitochondrial genome of the common sea slater, Ligia oceanica (Crustacea, Isopoda) bears a novel gene order and unusual control region features. BMC Genomics 2006, 7:241.

47. Bleidorn C, Eeckhaut I, Podsiadlowski L, Schult N, McHugh D, Halanych KM, Milinkovitch MC, Tiedemann R: Mitochondrial genome and nuclear sequence data support Myzostomida as part of the annelid radiation. Mol Biol Evol 2007, 24(8):1690-1701.

48. Bandyopadhyay PK, Stevenson BJ, Ownby JP, Cady MT, Watkins M, Olivera BM: The mitochondrial genome of Conus textile, coxl-coxll intergenic sequences and conoidean evolution. Mol Phylogenet Evol 2008, 46(1):215-223.

49. Simison WB, Lindberg DR, Boore JL: Rolling circle amplification of metazoan mitochondrial genomes. Mol Phylogenet Evol 2006, 39(2):562-567.

50. Bandyopadhyay PK, Stevenson BJ, Cady MT, Olivera BM, Wolstenholme DR: Complete mitochondrial DNA sequence of a Conoidean gastropod Lophiotoma (Xenuroturris) cerithiformis: gene order and gastropod phylogeny. Toxicon 2006, 48(1):29-43.

51. Maynard BT, Kerr LJ, McKiernan JM, Jansen ES, Hanna PJ: Mitochondrial DNA sequence and gene organization in Australian backup abalone Haliotis rubra (Leach). Mar Biotechnol 2005, 7(6):645-658.

52. Yokobori S, Fukuda N, Nakamura M, Aoyama T, Oshima T: Long-term conservation of six duplicated structural genes in cephalopod mitochondrial genomes. Mol Biol Evol 2004, 21(11):2034-2046.

53. Sundberg $P$, Turbeville JM, Lindh S: Phylogenetic relationships among higher nemertean (Nemertea) taxa inferred from 18S rDNA sequences. Mol Phylogenet Evol 2001, 20(3):327-334

54. Thollesson M, Norenburg JL: Ribbon worm relationships: a phylogeny of the phylum Nemertea. Proc Biol Sci 2003, 270(1513):407-415.

55. Andrade SCS, Strand M, Schwartz M, Chen HX, Kajihara H, von Döhren J, Sun SC, Junoy J, Thiel M, Norenburg JL, Turbeville JM, Giribet G, Sundberg P: Disentangling ribbon worm relationships: multi-locus analysis supports traditional classification of the phylum Nemertea. Cladistics 2011, 27:1-19.

56. Roe $P$, Norenburg JL: Observations on depth distributions, diversity and abundance of pelagic nemerteans from the Pacific Ocean off California and Hawaii. Deep-Sea Res 1999, 46:1201-1220.
57. Palumbi SMA, Romano S, McMillan WO, Stice L, Grabowski G: The simple fools guide to PCR Honolulu, Special publication Department of Zoology and Kewalo Marine Laboratory. University of Hawaii; 1991.

58. Boore JL, Brown WM: Mitochondrial genomes of Galathealinum, Helobdella, and Platynereis: sequence and gene arrangement comparisons indicate that Pogonophora is not a phylum and Annelida and Arthropoda are not sister taxa. Mol Biol Evol 2000, 17(1):87-106.

59. Folmer O, Black M, Hoeh W, Lutz R, Vrijenhoek R: DNA primers for amplification of mitochondrial cytochrome $c$ oxidase subunit I from diverse metazoan invertebrates. Mol Mar Biol Biotechnol 1994, 3(5):294-299.

60. Lowe TM, Eddy SR: tRNAscan-SE: a program for improved detection of transfer RNA genes in genomic sequence. Nucleic Acids Res 1997, 25(5):955-964.

61. De Rijk P, De Wachter R: RnaViz, a program for the visualisation of RNA secondary structure. Nucleic Acids Res 1997, 25(22):4679-4684.

62. Stothard P, Wishart DS: Circular genome visualization and exploration using CGView. Bioinformatics 2005, 21(4):537-539.

63. Tamura K, Dudley J, Nei M, Kumar S: MEGA4: Molecular Evolutionary Genetics Analysis (MEGA) software version 4.0. Mol Biol Evol 2007, 24(8):1596-1599.

64. Watterson GA, Ewens WJ, Hall TE, Morgan A: The chromosome inversion problem. J Theor Biol 1982, 99(1):1-7.

65. Bader DA, Moret BME, Yan M: A linear-time algorithm for computing inversion distance between signed permutations with an experimental study. J Comput Biol 2001, 8(5):483-491.

66. Thompson JD, Gibson TJ, Plewniak F, Jeanmougin F, Higgins DG: The CLUSTAL_X windows interface: flexible strategies for multiple sequence alignment aided by quality analysis tools. Nucleic Acids Res 1997, 25(24):4876-4882.

67. Castresana J: Selection of conserved blocks from multiple alignments for their use in phylogenetic analysis. Mol Biol Evol 2000, 17(4):540-552.

68. Giribet G, Distel DL, Polz M, Sterrer W, Wheeler WC: Triploblastic relationships with emphasis on the acoelomates and the position of Gnathostomulida, Cycliophora, Plathelminthes, and Chaetognatha: a combined approach of $18 \mathrm{~S}$ rDNA sequences and morphology. Syst Biol 2000, 49(3):539-562.

69. Dunn CW, Hejnol A, Matus DQ, Pang K, Browne WE, Smith SA, Seaver E, Rouse GW, Obst M, Edgecombe GD, et al: Broad phylogenomic sampling improves resolution of the animal tree of life. Nature 2008, 452(7188):745-749

70. Struck TH, Fisse F: Phylogenetic position of Nemertea derived from phylogenomic data. Mol Biol Evol 2008, 25(4):728-736.

71. Hejnol A, Obst M, Stamatakis A, Ott M, Rouse GW, Edgecombe GD, Martinez $P$, Baguna J, Bailly $X$, Jondelius $U$, et al: Assessing the root of bilaterian animals with scalable phylogenomic methods. Proc Biol Sci 2009, 276(1677):4261-4270.

72. Paps J, Baguna J, Riutort M: Bilaterian phylogeny: a broad sampling of 13 nuclear genes provides a new Lophotrochozoa phylogeny and supports a paraphyletic basal Acoelomorpha. Mol Biol Evol 2009, 26(10):2397-2406.

73. Paps J, Baguna J, Riutort M: Lophotrochozoa internal phylogeny: new insights from an up-to-date analysis of nuclear ribosomal genes. Proc Biol Sci 2009, 276(1660):1245-1254.

74. Stamatakis A: RAxML-VI-HPC: maximum likelihood-based phylogenetic analyses with thousands of taxa and mixed models. Bioinformatics 2006, 22(21):2688-2690.

75. Stamatakis A, Hoover P, Rougemont J: A rapid bootstrap algorithm for the RAxML Web servers. Syst Biol 2008, 57(5):758-771.

76. Miller MA, Holder MT, Vos R, Midford PE, Liebowitz T, Chan L, Hoover P, Warnow T: CIPRES (Cyberinfrastructure for Phylogenetic Research). 2009 [http://www.phylo.org/sub_sections/portal], Archived by website at: http:// www.webcitation.org/5imQlJeQa.

77. Ronquist F, Huelsenbeck JP: MrBayes 3: Bayesian phylogenetic inference under mixed models. Bioinformatics 2003, 19(12):1572-1574.

78. Huelsenbeck JP, Ronquist F: MRBAYES: Bayesian inference of phylogenetic trees. Bioinformatics 2001, 17(8):754-755.

79. Nylander JAA: MrModelTest Evolutionary Biology Centre Uppsala University: Nylander; 2004 [http://www.abc.se/ ].

80. Katoh K, Kuma K, Toh H, Miyata T: MAFFT version 5: improvement in accuracy of multiple sequence alignment. Nucleic Acids Res 2005, 33(2):511-518. 
81. Abascal F, Zardoya R, Posada D: ProtTest: selection of best-fit models of protein evolution. Bioinformatics 2005, 21(9):2104-2105.

82. Lartillot N, Lepage T, Blanquart S: PhyloBayes 3: a Bayesian software package for phylogenetic reconstruction and molecular dating. Bioinformatics 2009, 25(17):2286-2288.

doi:10.1186/1471-2164-13-139

Cite this article as: Chen et al: A comparative study of nemertean complete mitochondrial genomes, including two new ones for Nectonemertes cf. mirabilis and Zygeupolia rubens, may elucidate the fundamental pattern for the phylum Nemertea. BMC Genomics 2012 13:139.

Submit your next manuscript to BioMed Central and take full advantage of:

- Convenient online submission

- Thorough peer review

- No space constraints or color figure charges

- Immediate publication on acceptance

- Inclusion in PubMed, CAS, Scopus and Google Scholar

- Research which is freely available for redistribution

Submit your manuscript at www.biomedcentral.com/submit 